ISSN 0258-7122

Bangladesh J. Agril. Res. 37(3): 433-439, September 2012

\title{
EFFECT OF TIDAL SUBMERGENCE ON POTASSIUM NUTRITION AND YIELD OF RICE (Oryza sativa L.)
}

\begin{abstract}
M.A. HAQUE ${ }^{1}$
Abstract

Field experiments were conducted at Patuakhali Science and Technology University research farm during 2009 T. Aman season to investigate the effect of tidal submergence on potassium nutrition and yield of rice. The experiment included two levels of irrigation water source- i) tidal water and ii) ground water, and three levels of fertilizers- i) absolute control (no fertilizer), ii) NP (K omission), and iii) NPK (K addition). The rice varieties were BR23 (HYV) and Lalmota (traditional variety). A general increase in growth, yield and yield contributing parameters were found due to irrigation with tidal water. Tidal water contributed about 19\% (BR23) and 11\% (Lalmota) higher grain yield in Aman season 2009 compared to that grown with ground water. Potassium contents of rice grain and straw were always higher when plants are irrigated with tidal water. In general, tidal submergence increased $\mathrm{K}$ uptake of rice. The $\mathrm{K}$ uptake by BR23 under tidal water was about 47, 43 and $8 \mathrm{~kg} /$ ha more than those recorded with ground water irrigation under absolute control, $\mathrm{K}$ omission and $\mathrm{K}$ addition treatments, respectively whereas it was 31, 21, and $68 \mathrm{~kg} / \mathrm{ha}$, in Lalmota. The results indicated that whether fertilizers were applied or not plants absorb considerable amount of $\mathrm{K}$ from tidal water.
\end{abstract}

Keywords: Potassium, rice, tidal submergence.

\section{Introduction}

Potassium (K) mining from the soils is a serious problem of Bangladesh resulting substantial decrease in available K (Ali et al.,1997). The general recommended dose of $\mathrm{K}$ fertilizer for high yielding rice in Bangladesh is 50-70 kg K/ha (FRG, 2005). However, many farmers of the country do not apply $\mathrm{K}$ fertilizer to rice, as $\mathrm{K}$ deficiency symptoms are not as conspicuous as observed for $\mathrm{N}$ deficiency. Nevertheless, inappropriate $\mathrm{K}$ fertilizer management coupled with increasing cropping intensity with modern HYV led to K deficiency in many alluvial soils of Bangladesh. Omission of $\mathrm{K}$ fertilizer in rice-rice cropping systems may lower available $\mathrm{K}$ content in soil, resulting lower yield of rice.

Huge effort is given to develop $\mathrm{K}$ management strategy in high and medium high lands. However, less attention is made for $\mathrm{K}$ management in coastal tidal lands of Bangladesh. Farmers are very much reluctant to use $\mathrm{K}$ for rice production in this region. Generally farmers grow local rice varieties and getting

\footnotetext{
${ }^{1}$ Assistant Professor, Department of Soil Science, Patuakhali Science and Technology University (PSTU), Dumki, Patuakhali-8600, Bangladesh.
} 
satisfactory yield without applying any $\mathrm{K}$ fertilizers. Unfortunately what is the reason underlying this is not properly investigated. Coastal tidal lands are characterized by tidal inundation twice in a day. Tidal water carry huge amount of sediments which are expected to deposit in the rice field. Tidal sediments are an important source of primary, secondary and micro nutrients to tidal flooded soil. Nitrogen in the sediments is linked mainly to organic matter. Phosphorus, potassium and others are primarily associated with fine-grained clay minerals (Odum, 1988). Sediment deposition plays a critical role in the sustainable production of rice in the southern coastal tidal soils of Bangladesh, because tidal water increases plant height, tiller production, shoot weight, and nitrogen concentration and uptake of rice (Haque et al., 2008). Velocity and duration of flooding can influence sediment deposition and hence nutrient availability in tidal fresh water marshes (Darke and Megonigal, 2003). Sedimentation in tidal areas is generally highest during rainy-season when high river discharge and current of water increases riverbank erosion, fully covered rice field traps sediment on the tidal flooded marshes, nutrient uptake also increased as well (Morse et al., 2004). Moreover, the tidal water may contain soluble nutrients which may contribute to the nutrition of rice. Hence, in this situation a research is needed to quantify the contribution of tidal submergence made to nutrition of rice. The study was therefore undertaken to know the effect of tidal submergence to potassium nutrition of rice.

\section{Materials and Method}

Two similar field experiments were conducted during Aman season of 2009 at Patuakhali Science and Technology University research farm. Each experiment was laid out in split plot design which included two factors; first, 'source of irrigation water' consisting two levels: i) tidal water and ii) ground water, second factor, 'fertilizer' consisting three levels: i) absolute control (no fertilizer), ii) NP (K omission), and iii) NPK (K addition). Thus, six treatment combinations were used in the experiments. Each treatment was replicated three times. High yielding rice variety BR23 was used in one experiment and traditional variety Lalmota was used in another experiment. A highland was selected for the experiments so that natural tidal water cannot enter into the plot and amount of irrigation water could be control easily. Irrigation water requirement of this field was higher compared to the other medium high or low lands. The initial soil of the field experiments contained $0.09 \%$ total $\mathrm{N}, 12.6 \mathrm{ppm}$ available phosphorus, 0.39 me/100g soil exchangeable potassium, $46.5 \mathrm{ppm}$ available $\mathrm{S}, 1.72 \%$ organic matter and $\mathrm{pH}$ of 7.5. Thirty five days old seedlings were transplanted on $3^{\text {rd }}$ September 2009 with the plant spacing of $20 \times 20 \mathrm{~cm}$. Three to four seedlings were transplanted in each hill. Fertilizer application was made with 80, 20 and 60 $\mathrm{kg} / \mathrm{ha}$ of $\mathrm{N}, \mathrm{P}$ and $\mathrm{K}$, respectively. Phosphorus and $\mathrm{K}$ were applied during puddling and $\mathrm{N}$ was applied in two equal splits at 15 and 30 days after 
transplanting. Fertilizers were allocated in the plots according to the treatments. Weeding was done and pesticide was applied two times during urea fertilizer application. Tidal water was collected from a channel which was connected with Paira river and given to the respective plots using a low lift pump. Ground water receiving plots were irrigated with deep-tube-well water. About $2-3 \mathrm{~cm}$ water depth was maintained in each plot during the growth period so that each plant can absorb required amount of nutrients from irrigation water. Potassium content of tidal water and ground water were 3.79 and $2.27 \mathrm{ppm}$, respectively. Plants were harvested at maturity and subsequent measurement of plant height, tillers/hill, grains/panicle and grain and straw yields were done. Chemical analysis of grain and straw were done using standard methods. The data obtained in the experiments were statistically analysed using MSTAT computer software program.

\section{Results and Discussion}

\section{Yield contributing characters}

Plant height of BR23 was significantly influenced by irrigation water sources but it was insignificant in local Lalmota (Table 1). Higher plant height was recorded by tidal water compared to ground water. Table 1 shows that 4.3 and $1.1 \mathrm{~cm}$ plant height benefit was recorded due to tidal submergence in BR23 and Lalmota, respectively. Among the fertilizer treatments, NP and NPK treated plots gave higher and identical plant height in both the varieties. Tidal water significantly increased the number of tillers per square meter in BR23 but not in Lalmota. Table 1 shows that tidal submergence contributed about 23 numbers of higher tillers per square meter in both BR23 and Lalmota compared to ground water. Regarding fertilizer treatments omission or addition of $\mathrm{K}$ produced statistically identical number of tillers per square meter in Lalmota but higher tillers were recorded by $\mathrm{K}$ addition plots of BR23.

Filled grains per panicle of BR23 and Lalmota were not significantly influenced by irrigation water sources, but $13 \%$ higher number of grains per panicle was recorded by BR23 due to tidal water treatment. Table 1 shows that addition or omission of K produced identical number of grains per panicle. Grain production capacity was found higher in BR23 compared to Lalmota. Percent sterility was significantly influenced by irrigation water sources in BR23 but was not significant in local Lalmota (Table 2). Forty six and 34 percent less sterility were found in tidal water treatments compared to ground water in the varieties BR23 and Lalmota, respectively. Among the fertilizer treatments, and interactions among irrigation water and fertilizers, no significant difference in percent sterility was noted in both rice varieties. Thousand grain weight of two rice varieties was significantly influenced by irrigation water sources and 
fertilizer treatments but consistent result was not observed. Table 2 shows that $\mathrm{K}$ omission or addition gave identical grain weight.

Table 1. Plant height $(\mathrm{cm})$, tillers $/ \mathrm{m}^{2}$ and filled grains/panicle of rice varieties as influenced by irrigation water sources and fertilizers, Aman 2009.

\begin{tabular}{|c|c|c|c|c|c|c|}
\hline \multirow{2}{*}{ Treatments } & \multicolumn{2}{|c|}{ Plant height } & \multicolumn{2}{|c|}{ Tillers $/ \mathrm{m}^{2}$} & \multicolumn{2}{|c|}{ Filled grains/panicle } \\
\hline & BR23 & Lalmota & BR23 & Lalmota & BR23 & Lalmota \\
\hline \multicolumn{7}{|l|}{ Irrigation } \\
\hline Tidal water & $112.0 \mathrm{a}$ & 130.7 & 190.22 a & 196.56 & 120.12 & 68.70 \\
\hline Ground water & $107.7 \mathrm{~b}$ & 129.6 & $167.22 \mathrm{~b}$ & 173.67 & 106.22 & 67.76 \\
\hline \multicolumn{7}{|l|}{ Fertilizer } \\
\hline Control & $104.5 \mathrm{~b}$ & $120.3 \mathrm{~b}$ & 153.67 c & $127.17 \mathrm{~b}$ & $96.22 \mathrm{~b}$ & $63.33 \mathrm{~b}$ \\
\hline K omission & $113.0 \mathrm{a}$ & 134.5 a & $183.83 \mathrm{~b}$ & $215.00 \mathrm{a}$ & $123.10 \mathrm{a}$ & 66.37 a \\
\hline NPK & $112.0 \mathrm{a}$ & 135.5 a & 198.67 a & 213.17 a & 120.20 a & 74.98 a \\
\hline \multicolumn{7}{|l|}{ Irrigation $\times$ Fertilizer } \\
\hline Tidal water $\times$ Control & 105.7 & $123.3 \mathrm{~b}$ & $169.00 \mathrm{~b}$ & $159.33 \mathrm{~b}$ & 109.70 & $59.33 \mathrm{~b}$ \\
\hline $\begin{array}{l}\text { Tidal water } \times \mathrm{K} \\
\text { omission }\end{array}$ & 114.7 & $133.0 \mathrm{a}$ & 200.33 a & 222.33 a & 126.6 & $64.37 \mathrm{~b}$ \\
\hline Tidal water $\times$ NPK & 115.7 & 135.7 a & 201.33 a & 208.00 a & 124.000 & 82.40 a \\
\hline $\begin{array}{l}\text { Ground water× } \\
\text { Control }\end{array}$ & 103.3 & $117.3 \mathrm{c}$ & 138.33 c & $95.00 \mathrm{c}$ & 82.73 & $67.33 \mathrm{~b}$ \\
\hline $\begin{array}{l}\text { Ground water } \times \mathrm{K} \\
\text { omission }\end{array}$ & 111.3 & 136.0 a & $167.33 \mathrm{~b}$ & 207.67 a & 119.53 & $68.37 \mathrm{~b}$ \\
\hline Ground water×NPK & 108.3 & 135.3 а & $196.00 \mathrm{a}$ & 218.33 a & 116.40 & $67.57 \mathrm{~b}$ \\
\hline
\end{tabular}

Common letters in a column are not significantly different at $5 \%$ level by DMRT

\section{Grain and straw yield}

Grain yield of BR23 and Lalmota was significantly influenced by both irrigation water sources and fertilizer treatments (Table 2). The highest grain yield of 4.489 and 3.351 t/ha was recorded by tidal water in BR23 and Local Lalmota, respectively, which was about 19 and $11 \%$ higher than the respective ground water treatment. Regarding fertilizer treatments, $\mathrm{K}$ omission or $\mathrm{K}$ addition gave statistically identical yield. Interaction effects between irrigation water sources and fertilizers on grain yield of both the varieties of rice were not significant. Regarding BR23 highest of 5.284 t/ha grain yield was recorded by tidal water $\times$ NPK treatment, second highest yield (4.949 t/ha) was recorded by tidal water $\times \mathrm{K}$ omission and third highest yield (4.623 t/ha) was recorded by ground water $\times \mathrm{NPK}$ treatment. Regarding Lalmota this pattern was tidal water $\times \mathrm{K}$ 
omission (3.956 t/ha)> tidal water $\times$ NPK treatment $(3.776 \mathrm{t} / \mathrm{ha})>$ ground water $\times$ NPK treatment (3.597)> ground water $\times K$ omission treatment $(3.322 \mathrm{t} / \mathrm{ha})$. Thus table 2 indicated that when plants received tidal water they performed better in all fertilizer treatments compared to ground water treated plots and it was caused due to the absorption of $\mathrm{K}$ from tidal water. Straw yield was significantly influenced by irrigation water sources and fertilizer treatments in both the rice varieties (Table 3). BR23 and Lalmota recorded 5.51 and 6.563 t/ha straw yield, respectively, in tidal water; whereas it was 4.90 and 5.515 t/ha in ground water treatments. About 0.6 and 1.0 t/ha higher straw yield was contributed by tidal water compared to ground water in BR23 and Lalmota, respectively. Remarkable variation was not found in $\mathrm{K}$ omitted or $\mathrm{K}$ added plots of Lalmota, but it was significant in BR23. Interaction effects among tidal water and fertilizers were significant in BR23 but it was insignificant regarding Lalmota.

Table 2. Percent sterility, 1000-grain wt (g) and grain yield (t/ha) of rice varieties as influenced by irrigation water sources and fertilizers, Aman, 2009.

\begin{tabular}{|c|c|c|c|c|c|c|}
\hline \multirow{2}{*}{ Treatments } & \multicolumn{2}{|c|}{ \% sterility } & \multicolumn{2}{|c|}{ 1000-grain wt } & \multicolumn{2}{|c|}{ Grain yield } \\
\hline & BR23 & Lalmota & BR23 & Lalmota & BR23 & Lalmota \\
\hline \multicolumn{7}{|l|}{ Irrigation } \\
\hline Tidal water & $14.77 \mathrm{~b}$ & 11.80 & $23.45 \mathrm{~b}$ & 28.45 a & $4.489 \mathrm{a}$ & $3.351 \mathrm{a}$ \\
\hline Ground water & 21.58 a & 15.81 & 24.86 a & $27.70 \mathrm{~b}$ & $3.763 \mathrm{~b}$ & $3.029 \mathrm{~b}$ \\
\hline \multicolumn{7}{|l|}{ Fertilizer } \\
\hline Control & 18.20 & 13.97 & 24.95 a & $26.53 \mathrm{~b}$ & $2.738 \mathrm{~b}$ & $2.244 \mathrm{~b}$ \\
\hline K omission & 15.82 & 14.70 & $23.68 \mathrm{~b}$ & 28.75 a & 4.686 a & 3.639 a \\
\hline NPK & 20.50 & 12.75 & $23.84 \mathrm{~b}$ & 28.95 a & $4.953 \mathrm{a}$ & 3.686 a \\
\hline \multicolumn{7}{|l|}{ Irrigation $\times$ Fertilizer } \\
\hline Tidal water $\times$ Control & 16.80 & 11.37 & $24.60 \mathrm{ab}$ & 26.66 & 3.234 & 2.320 \\
\hline $\begin{array}{l}\text { Tidal water } \times \mathrm{K} \\
\text { omission }\end{array}$ & 11.63 & 12.97 & $22.00 \mathrm{c}$ & 29.35 & 4.949 & 3.956 \\
\hline Tidal water $\times$ NPK & 15.87 & 11.07 & $23.76 \mathrm{~b}$ & 29.33 & 5.284 & 3.776 \\
\hline $\begin{array}{l}\text { Ground water× } \\
\text { Control }\end{array}$ & 19.60 & 16.57 & $25.30 \mathrm{a}$ & 26.40 & 2.243 & 2.167 \\
\hline $\begin{array}{l}\text { Ground water } \times \mathrm{K} \\
\text { omission }\end{array}$ & 20.00 & 16.43 & 25.36 a & 28.15 & 4.423 & 3.322 \\
\hline Ground water $\times$ NPK & 25.13 & 14.43 & $23.92 b$ & 28.56 & 4.623 & 3.597 \\
\hline
\end{tabular}

Common letters in a column are not significantly different at $5 \%$ level by DMRT 
Table 3. Straw yield (t/ha), and grain and straw potassium content (\%) of rice varieties as influenced by irrigation water sources and fertilizers, Aman 2009.

\begin{tabular}{|c|c|c|c|c|c|c|}
\hline \multirow{2}{*}{ Treatments } & \multicolumn{2}{|c|}{ Straw yield } & \multicolumn{2}{|c|}{ Grain K-content } & \multicolumn{2}{|c|}{ Straw K content } \\
\hline & BR23 & Lalmota & BR23 & Lalmota & BR23 & Lalmota \\
\hline \multicolumn{7}{|l|}{ Irrigation } \\
\hline Tidal water & $5.510 \mathrm{a}$ & 6.563 a & 0.182 & 0.197 a & 2.349 a & $2.652 \mathrm{a}$ \\
\hline Ground water & $4.900 \mathrm{~b}$ & $5.515 \mathrm{~b}$ & 0.186 & $0.182 \mathrm{~b}$ & $1.970 \mathrm{~b}$ & $2.273 \mathrm{~b}$ \\
\hline \multicolumn{7}{|l|}{ Fertilizer } \\
\hline Control & $3.958 \mathrm{~b}$ & $4.015 \mathrm{~b}$ & 0.182 & $0.171 \mathrm{~b}$ & $2.046 \mathrm{~b}$ & $1.818 \mathrm{~b}$ \\
\hline K omission & 5.618 a & 6.780 a & 0.177 & 0.193 a & $1.932 \mathrm{~b}$ & $2.841 \mathrm{a}$ \\
\hline NPK & 6.039 а & 7.320 a & 0.193 & 0.205 a & $2.500 \mathrm{a}$ & 2.727 a \\
\hline \multicolumn{7}{|l|}{ Irrigation $\times$ Fertilizer } \\
\hline Tidal water $\times$ Control & $4.628 \mathrm{~b}$ & 4.331 & 0.182 & 0.182 & 2.273 & 2.045 \\
\hline $\begin{array}{l}\text { Tidal water } \times \mathrm{K} \\
\text { omission }\end{array}$ & 5.701 a & 7.399 & 0.182 & 0.205 & 2.273 & 2.955 \\
\hline Tidal water $\times$ NPK & 6.201 a & 7.958 & 0.182 & 0.205 & 2.500 & 2.955 \\
\hline $\begin{array}{l}\text { Ground water× } \\
\text { Control }\end{array}$ & 3.289 c & 3.700 & 0.182 & 0.159 & 1.818 & 1.591 \\
\hline $\begin{array}{l}\text { Ground water } \times \mathrm{K} \\
\text { omission }\end{array}$ & 5.535 a & 6.161 & 0.171 & 0.182 & 1.591 & 2.727 \\
\hline Ground water $\times$ NPK & 5.878 а & 6.682 & 0.205 & 0.205 & 2.500 & 2.500 \\
\hline
\end{tabular}

Common letters in a column are not significantly different at $5 \%$ level by DMRT

\section{Nutrient content}

Potassium content of rice straw was significantly influenced by both irrigation water sources and fertilizer treatments (Table 3). Tidal water always showed significantly higher $\mathrm{K}$ content than ground water. Potassium content was found higher when plants were fertilized with NPK in BR23, but regarding Lalmota, it was identical with $\mathrm{K}$ omission treatment. Grain $\mathrm{K}$ content of Lalmota was significantly influenced by irrigation water sources and fertilizers but it was not significant in BR23 (Table 3). A general increasing trend of $\mathrm{K}$ uptake by both the rice varieties was found in tidal water irrigation condition. Potassium uptake by BR23 under tidal water treatment was about 47,43 and $8 \mathrm{~kg} / \mathrm{ha}$ more as compared to ground water in absolute control, $\mathrm{K}$ omission and $\mathrm{K}$ addition treatments, respectively (Figure 1). Regarding Lalmota it was 31, 21, and 68.4 $\mathrm{kg} / \mathrm{ha}$, respectively. The results indicated that whether fertilizers were applied or not plants absorb considerable amount of $\mathrm{K}$ from tidal water. 


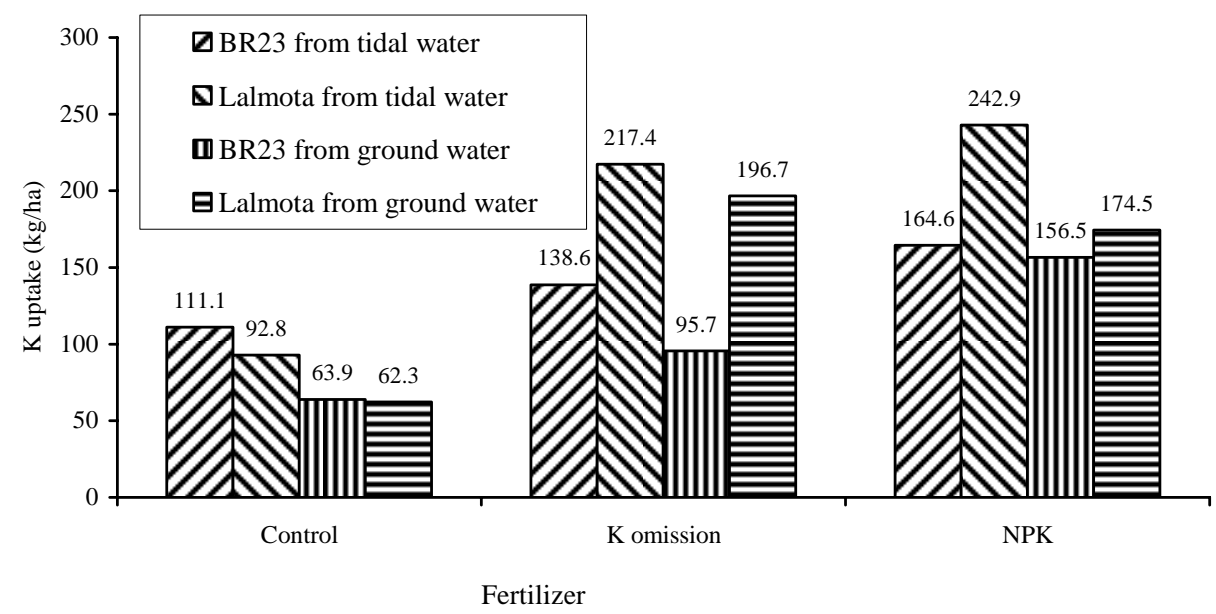

Figure 1. Potassium uptake by two rice varieties from two water sources, Aman 2009.

\section{Conclusion}

Tidal submergence is an important source of $\mathrm{K}$. It increases all the growth parameters along with yield of rice. It supplies considerable quantities of $\mathrm{K}$, however, it can not meet the total $\mathrm{K}$ requirement of rice.

\section{Acknowledgement}

I thank University Grants Commission, Bangladesh for financial support through the "Contribution of Tidal Sediments to Soil Fertility and Crop Yield" project to conduct the study.

\section{References}

Ali, M.M., S.M. Saheed, D. Kubota, T. Masunaga, and T. Wakatsuki. 1997. Soil degradation during the period 1967-1995 in Bangladesh. II. Selected chemical characters. Soil Sci. Plant Nutri. 43: 879-890.

Darke A.K. and J.P. Megonigal. 2003. Control of sediment deposition rates in two midAtlantic coast tidal freshwater wetlands. Estuarine, Coastal Shelf Sci. 57 (1-2): 259-272.

FRG (Fertilizer Recommendation Guide). 2005. Bangladesh Agricultural Research Council. Farmgate, Dhaka.

Haque, M.A., A. Khatun, D.E. Jharna and M.A. Saleque. 2008. Effect of tidal water flooding on growth and nitrogen uptake of rice. Intl. J. BioRes. 5(2):1-5.

Morse J.L., J.P. Megonigal and M.R. Walbridge. 2004. Sediment nutrient accumulation and nutrient availability in two tidal freshwater marshes along the Mattaponi River, Virginia, USA. Biogeochemistry 69: 175-206.

Odum W.E. 1988. Comparative ecology of tidal freshwater and salt marshes. Ann. Rev. Ecol. Syst. 19: 147-176. 